\title{
Kajian HKSA Antimalaria Senyawa Turunan Quinolon-4(1H)-imines Menggunakan Metode MLR-ANN
}

\author{
Jafar La Kilo ${ }^{1 *}$, Akram La Kilo ${ }^{2}$ \\ ${ }^{1,2}$ Program Studi Kimia, FMIPA Universitas Negeri Gorontalo
}

*Corresponding author:

email: jafar.chem@ung.ac.id

Received: 18 March, 2019

Accepted: 19 March, 2019

Online : 20 March, 2019
Abstract. Quantitatif Structure-Activity Relationship (QSAR) study of 22 antimalarial compounds of Quinolon-4(1H)-imines derivatives has been done using multilinear regression (MLR) and artificial neural network (ANN) methods. The best QSAR model was obtained from ANN analysis indicated by its higher correlation coefficient $\left(r^{2}\right)$ compared to MLR method, i.e. 0.931 with most influential descriptors is $q C 1, q C 5, q C 11, q N 14$ and $\log P$.

Keywords: Quinolon-4(1H)-imines, Antimalarial, QSAR, MLR-ANN

Abstrak. Telah dilakukan kajian analisis Hubungan Kuantitatif Struktur Aktivitas (HKSA) terhadap 22 senyawa antimalaria turunan Quinolon$4(1 \mathrm{H})$-imines menggunakan metode regresi multilinear (MLR) dan artificial neural network (ANN). Model HKSA terbaik diperoleh dari hasil analisis menggunakan metode ANN yang ditunjukkan oleh nilai koefisien korelasi $\left(\mathrm{r}^{2}\right)$ paling tinggi dibandingkan dengan metode MLR yaitu sebesar 0,931 dengan deskriptor paling berpengaruh terhadap aktivitas antimalaria turunan Quinolon- $4(1 \mathrm{H})$-imines, yaitu qC1, qC5, qC11, qN14 dan log P.

Kata Kunci: Quinolon-4(1H)-imines, Antimalaria, HKSA, MLR-ANN

\section{PENDAHULUAN}

Malaria merupakan salah satu jenis penyakit paling berbahaya di dunia yang disebabkan oleh lima jenis parasit dari genus Plasmodium yang menginfeksi manusia yaitu Plasmodium falciparum, Plasmodium vivax, Plasmodium ovale, Plasmodium malariae dan Plasmodium knowlesi. Secara global, diperkirakan 3,4 miliar orang berada pada risiko terserang malaria setiap tahun. Tahun 2012 terjadi 207 juta kasus malaria di seluruh dunia, 627 ribu diantaranya meninggal dunia (WHO, 2013). Oleh karena itu, diperlukan langkah pencegahan untuk meminimalisir kasus tersebut. Salah satu langkah pencegahan yang dapat dilakukan adalah dengan pengobatan.

Artemisinin menjadi standar sebagai antimalaria saat ini. Telah muncul tanda-tanda beberapa virus penyebab malaria resisten terhadap artemisinin (Dondorp et al., 2009). Chloroquinon yang dikenal luas sebagai agen antimalaria utama selama beberapa dekade. Namun, saat ini chloroquinon telah kehilangan kemanjurannya khususnya di daerah endemik besar akibat pesatnya perkembangan resistensi obat (Kaur, Jain, Reddy, \& Jain, 2010).
Salah satu senyawa yang saat ini dikembangkan sebagai antimalaria adalah Quinolon-4(1H)-imines. Pengembangan Quinolon-4(1H)-imines sebagai antimalaria baru dapat dilakukan dengan pendekatan Quantitative Structure-Activity Relationship (QSAR) atau Hubungan Kuantitatif Struktur-Aktivitas (HKSA). Pendekatan HKSA menghubungkan aktivitas biologi dengan deskriptor yang berbasis mekanika kuantum (Verma \& Hansch, 2009). Hubungan antara deskriptor dengan aktivitas biologi diformulasikan dalam satu persamaan. Berdasarkan persamaan HKSA dapat diprediksi sisi paling aktif suatu molekul obat. Hal ini dapat mengurangi kegagalan riset-riset ekperimental dalam laboratorium dan dapat mengefisienkan tenaga, biaya, mengurangi penggunaan hewan uji serta melindungi lingkungan dari berbagai pencemar yang bersifat toksik. Persamaan HKSA dihasilkan dari analisis statistik multivariat. Multiple linear regression (MLR) merupakan metode statistik yang banyak digunakan dalam kajian HKSA, akan tetapi hasil analisis dengan metode ini akurasinya rendah (Larif et al., 2013). Karena dalam MLR hubungan antara struktur dan aktivitas digambarkan sebagai hubungan linear, 
padahal dalam fenomena secara biologi hubungan yang terjadi tidak hanya linear dikarenakan kontribusi beberapa deskriptor terhadap aktivitas juga dapat berupa hubungan non-linear. Oleh karena itu, dalam penelitian ini, selain menggunakan metode MLR (analisis hubungan linear), digunakan juga metode artificial neural network (ANN) untuk analisis hubungan non linear. Metode ANN telah banyak digunakan dalam kajian HKSA, antara lain oleh (Su \& Zhou, 2006), (Habibi-Yangjeh, Danandeh-Jenagharad, \& Nooshyar, 2006) (Ventura, Latino, \& Martins, 2013), (Goodarzi, Freitas, \& Ghasemi, 2010), dan hasilnya lebih baik dari metode MLR.

\section{METODE PENELITIAN}

\section{Bahan Kajian}

Senyawa turunan Quinolon-4(1H)-imines yang disertai dengan nilai aktivitas $\left(\mathrm{IC}_{50}\right)$ (Ressurreição et al., n.d.) untuk melawan virus $P$. falciparum W2 (lihat tabel I).<smiles>[R]c1ccc(N=c2ccn([R])c3cc([R])c([R])cc23)cc1</smiles>

Gambar 1. Struktur Quinolon-4(1H)-imines

\section{Peralatan}

Komputer personal dengan prosesor Intel ${ }^{\circledR}$ Pentium IV dengan kapasitas $1,5 \mathrm{GHz}$ dan RAM 1 GB. Perangkat lunak yang digunakan meliputi, GaussView 5.0, Gaussian®09W (G09W), HyperChem $^{\mathrm{TM}}$ 8.0.10, SPSS ${ }^{8}$ Release 16.0.0, MATLAB versi 7.8.0.347 (R2009a)

\section{Prosedur}

\section{Perhitungan deskriptor}

Deskriptor yang digunakan dalam penelitian ini adalah deskriptor elektronik yang meliputi, muatan atom bersih (q), momen dipol $(\mu)$, energi HOMO (highest occupied molecular orbital), LUMO (lowest unoccupied molecular orbital) yang dihitung menggunakan metode $a b$ initio/Hartree-Fock pada program mekanika kuantum G09W dan deskriptor molekul, yaitu koefisien partisi (log P), luas permukaan, volume, refraktivitas, polarisabilitas dan massa molekul yang dihitung menggunakan HyperChem ${ }^{\mathrm{TM}}$ 8.0.10.

\section{Penyusunan Model}

Sejumlah 22 senyawa antimalaria yang digunakan dalam penelitian ini, dibagi secara random menjadi dua kelompok data yaitu training set dan test set (huruf tebal, tabel I). Selanjutnya, senyawa training set dianalisis menggunakan multilinear regression (MLR) dengan metode backward yang dijalankan pada program SPSS $\AA$ Release 16.0.0 untuk mendapatkan beberapa model hubungan antara log $I_{50}$ dengan deskriptor elektronik dan molekul (model HKSA). Deskriptor-deskriptor yang didapatkan dari model HKSA terbaik dari hasil analisis MLR selanjutnya digunakan sebagai input dalam penyusunan model dengan metode ANN menggunakan program MATLAB versi 7.8.0.347.

\section{Validasi Model}

Beberapa model yang dihasilkan dari analisis MLR, divalidasi untuk mendapatkan model terbaik. Model yang dipilih (valid) didasarkan pada nilai $r^{2}$, SEE, dan nilai $F_{\text {hitung }} / F_{\text {tabel }}$. Parameterparameter tersebut harus memenuhi kriteria, dimana nilai ${ }^{2}>0,6$ (Golbraikh, Shen, Xiao, Xiao, \& Lee, 2003); SEE < 0,3 (Mishra, Mishra, Senger, Pathak, \& Kashaw, 2013); $F_{\text {hitung }} / F_{\text {tabel }} \geq 1$ (Motta \& Almeida, 2011) dan memiliki nilai Prediction Sum of Square (PRESS) paling kecil. Persamaan akhir HKSA diambil dari hasil analisis menggunakan metode ANN, dimana nilai $r_{\text {pred }}^{2}$ harus lebih besar dari $0,5\left(r_{\text {pred }}^{2}>0,5\right)$ (Frimayanti, Yam, Lee, \& Othman, 2011).

\section{HASIL DAN PEMBAHASAN}

\section{Analisis HKSA dengan Metode MLR}

Berdasarkan hasil analisis statistik dengan metode MLR (backward) dihasilkan delapan model persamaan HKSA yang memiliki nilai $r^{2}$ lebih besar dari 0,81 (memenuhi kriteria yang ditetapkan). Hal ini menggambarkan pengaruh variabel bebas (deskriptor) yang 
digunakan terhadap aktivitas antimalaria sangat besar, yaitu lebih dari $81 \%$. Begitu juga dengan parameter SEE. Nilai SEE untuk semua model kurang dari 0,21. Nilai ini menunjukan akurasi model yang dihasilkan untuk memprediksi senyawa antimalaria baru sangat baik (mendekati 0 ). Adapun parameter $F_{\text {hit }} / F_{\text {tab }}$, yang menunjukan tingkat signifikansi (pengaruh deskriptor terhadap aktivitas). Untuk model 1 sampai 6 tidak signifikan karena memiliki nilai $F_{\text {hit }} / F_{\text {tab }}$ kurang dari 1 (tidak memenuhi kriteria) untuk tingkat signifikansi 95\%. Model yang memenuhi kriteria di atas adalah model 7 dan 8 yaitu memiliki nilai $F_{\text {hit }} / F_{\text {tab }}$ lebih dari 1. Kedua model ini divalidasi menggunakan nilai PRESS dari test set untuk mendapatkan model HKSA terbaik.

Validasi lanjutan dilakukan dengan menghitung nilai PRESS dari test set. Data PRESS diperoleh dari kuadrat selisih nilai aktivitas antimalaria hasil eksperimen dengan aktivitas prediksi berdasarkan model-model terpilih. Nilai PRESS menunjukan seberapa besar kesalahan yang dihasilkan dari model, semakin kecil nilai PRESS menunjukan model tersebut semakin baik. Berdasarkan hasil validasi, nilai PRESS terbaik ditunjukan oleh model 8 yaitu sebesar 0,528, lebih kecil dari model 7, yaitu sebesar 0.737. Dengan demikian, model 8 merupakan model HKSA terbaik yang melibatkan deskriptor qC1, qC5, qC11, qN14 dan log P. Selanjutnya, deskriptor yang terlibat dalam model HKSA terbaik ini dijadikan sebagai data input dalam analisis model HKSA menggunakan metode ANN.

\section{Analisis HKSA dengan Metode ANN}

Metode ANN digunakan untuk meningkatkan korelasi antara aktivitas biologi hasil eksperimen dengan hasil prediksi dari hasil analisis regresi linear. Data input dalam analisis ANN adalah deskriptor yang terlibat dalam model persamaan HKSA terbaik hasil analisis MLR. Penelitian ini menggunakan metode back-propagation dengan input layer terdiri dari 5 syaraf tiruan.

Dari analisis menggunakan metode ANN, didapatkan pola jaringan syaraf terbaik, 5-9-1 (gambar 2) dengan iterasi 5000 kali dan laju pemahaman optimum sebesar 0,3. Hasil analisis ANN juga menunjukan adanya hubungan yang kuat antara deskriptor dan aktivitas antimalaria $\left(\log \mathrm{IC}_{50}\right.$ ), hal ini ditandai dengan besarnya nilai koefisien korelasi $\left(r^{2}\right.$ pred) baik test set maupun training set, yaitu masing-masing sebesar 0,93 dan 0,96 .

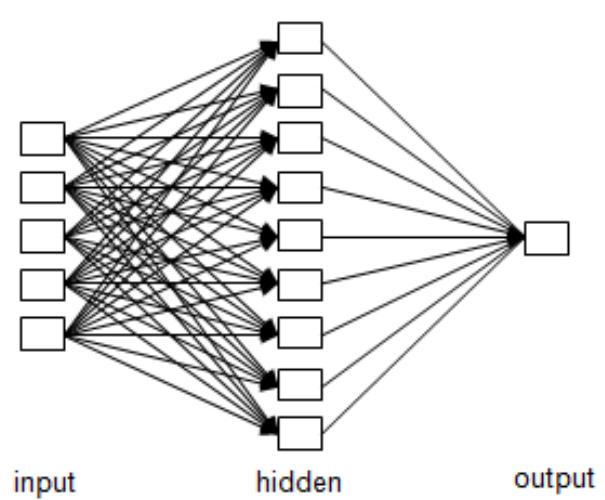

Gambar 2. Arsitektur ANN Terbaik 9-5-1

Nilai ini lebih baik dari hasil analisis menggunakan metode MLR dan juga memenuhi k kriteria yang ditetapkan, yaitu $r_{\text {pred }}^{2}>0,5$. Perbandingan hasil MLR dengan ANN (total data) ditampilkan pada tabel II.

Berdasarakan tabel II, dapat diketahui bahwa hasil analisis menggunakan metode ANN lebih baik dibandingkan dengan hasil analisis dengan metode MLR atau dapat pula diartikan bahwa, metode ANN memiliki kemampuan yang lebih baik dalam menggambarkan hubungan kuantitatif antara struktur dan aktivitas antimalaria senyawa turunan Quinolon-4(1H)-imines dibandingkan. dengan metode MLR. Hal ini ditandai dengan nilai PRESS hasil analisis dengan metode ANN lebih kecil yaitu sebesar 0,233 dibandingkan metode MLR sebesar 0,575. Dengan demikian, antara struktur dan aktivitas antimalaria senyawa turunan Quinolon-4(1H)imines tidak hanya terdapat hubungan linear, tetapi juga hubungan non linear. Selain itu, model yang didapat dari analisis ANN dapat digunakan untuk memprediksi senyawa antimalaria baru. Berbeda dengan model pada metode MLR, model HKSA dalam ANN melibatkan bobot dan bias, yang menghubungkan input layer dengan hidden layer atau hidden layer dengan output layer.

\section{Analisis Hubungan Struktur-aktivitas}

Muatan atom $\mathrm{C}_{1}, \mathrm{C}_{5}, \mathrm{C}_{11}$ dan $\mathrm{N}_{14}$ Quinolon-4(1H)-imines masing-masing bernilai negatif. Hal ini disebabkan oleh atom-atom tersebut mengikat gugus penyumbang elektron, sehingga kerapatan elektron akan menjadi lebih besar. Nilai muatan $\mathrm{C}_{11}$ relatif sama karena atom $\mathrm{C}_{11}$ untuk seluruh senyawa mengikat atom $\mathrm{H}$ dan pengaruh dari atom lain disekitarnya sangat kecil atau bahkan tidak ada. Sedangkan nilai muatan atom $\mathrm{C}_{1}$ dan $\mathrm{C}_{5}$ dipengaruhi oleh adanya subtituen yang terikat pada atom $\mathrm{C}_{6}$. Nilai atom $\mathrm{C}_{1}$ 
Tabel 1. Aktivitas Antimalaria Turunan Quinolon-4(1H)-imines

\begin{tabular}{|c|c|c|c|c|c|c|}
\hline No & $R_{1}$ & $\mathbf{R}_{\mathbf{2}}$ & $\mathbf{R}_{3}$ & $\mathbf{R}_{4}$ & $\mathrm{IC}_{50}(\mathrm{nM})$ & $\mathrm{pIC}_{50}$ \\
\hline $5 a$ & $\mathrm{Cl}$ & $\mathrm{H}$ & $\mathrm{Ph}$ & N,N-diethylpropan-1-amine & 491 & 2.7 \\
\hline $5 b$ & $\mathrm{Cl}$ & $\mathrm{H}$ & $\mathrm{Ph}$ & 1-propylpyrrolidine & 111 & 2.05 \\
\hline $5 c$ & $\mathrm{Cl}$ & $\mathrm{H}$ & $\mathrm{Ph}$ & 1-butylpiperidine & 144 & 2.16 \\
\hline $5 d$ & $\mathrm{Cl}$ & $\mathrm{H}$ & $\mathrm{Cl}$ & 1-butylpiperidine & 259 & 2.41 \\
\hline $5 e$ & $\mathrm{Cl}$ & $\mathrm{H}$ & $\mathrm{Br}$ & 1-butylpiperidine & 74,0 & 1.87 \\
\hline $5 f$ & $\mathrm{Cl}$ & $\mathrm{H}$ & $\mathrm{H}$ & 1-butylpiperidine & 273 & 2.44 \\
\hline $5 g$ & $\mathrm{Cl}$ & $\mathrm{H}$ & $\mathrm{CH}_{3}$ & 1-butylpiperidine & 331 & 2.52 \\
\hline $5 h$ & $\mathrm{Cl}$ & $\mathrm{H}$ & $\mathrm{F}$ & 1-butylpiperidine & 369 & 2.57 \\
\hline $5 i$ & $\mathrm{Cl}$ & $\mathrm{H}$ & anisole & 1-butylpiperidine & 160 & 2.2 \\
\hline $5 j$ & $\mathrm{CF}_{3}$ & $\mathrm{H}$ & $\mathrm{Ph}$ & $\mathrm{N}, \mathrm{N}$-diethylpropan-1-amine & 525 & 2.72 \\
\hline $5 \mathrm{k}$ & $\mathrm{CF}_{3}$ & $\mathrm{H}$ & $\mathrm{Ph}$ & 1-propylpyrrolidine & 226 & 2.35 \\
\hline 51 & $\mathrm{CF}_{3}$ & $\mathrm{H}$ & $\mathrm{Ph}$ & 1-butylpiperidine & 360 & 2.56 \\
\hline $5 m$ & 1-fluoro-4-methylbenzene & $\mathrm{H}$ & $\mathrm{H}$ & 1-butylpiperidine & 216 & 2.33 \\
\hline $5 n$ & 1-fluoro-4-methylbenzene & $\mathrm{H}$ & $\mathrm{Ph}$ & 1-butylpiperidine & 55,4 & 1.74 \\
\hline 50 & $\mathrm{~N}$-methylpyridin-2-amine & $\mathrm{H}$ & $\mathrm{Ph}$ & 1-butylpiperidine & 357 & 2.55 \\
\hline $5 p$ & quinoline & $\mathrm{H}$ & $\mathrm{Ph}$ & 1-butylpiperidine & 53,7 & 1.73 \\
\hline $5 q$ & $\mathrm{Cl}$ & $\mathrm{H}$ & $\mathrm{Ph}$ & N,N-diethylbutan-1-amine & 151 & 2.18 \\
\hline $5 r$ & $\mathrm{Cl}$ & $\mathrm{H}$ & $\mathrm{Ph}$ & $\mathrm{N}, \mathrm{N}$-diethylpentan-1-amine & 67,6 & 1.83 \\
\hline $5 s$ & $\mathrm{CF}_{3}$ & $\mathrm{H}$ & $\mathrm{Ph}$ & $\mathrm{N}, \mathrm{N}$-diethylbutan-1-amine & 144 & 2.16 \\
\hline $5 t$ & $\mathrm{CF}_{3}$ & $\mathrm{H}$ & $\mathrm{Ph}$ & $\mathrm{N}, \mathrm{N}$-diethylpentan-1-amine & 50,3 & 1.70 \\
\hline $5 u$ & $\mathrm{H}$ & $\mathrm{Cl}$ & $\mathrm{Ph}$ & 1-butylpiperidine & 99,7 & 2.00 \\
\hline $5 v$ & $\mathrm{H}$ & $\mathrm{CF}_{3}$ & $\mathrm{Ph}$ & 1-butylpiperidine & 631 & 2.80 \\
\hline
\end{tabular}

Tabel 2. Nilai Aktivitas Antimalaria Hasil Prediksi dan Eksperimen

\begin{tabular}{cccc}
\hline \multirow{2}{*}{ No } & \multicolumn{3}{c}{ Aktivitas antimalaria $\left(\log \mathbf{~ I C}_{50}\right)$} \\
\cline { 2 - 4 } & Ekperimen & MLR & ANN \\
\hline $5 \mathrm{a}$ & 2.697 & 2.515 & 2.689 \\
$5 \mathrm{~b}$ & 2.045 & 2.102 & 2.047 \\
$5 \mathrm{c}$ & 2.158 & 2.193 & 2.166 \\
$5 \mathrm{~d}$ & 2.413 & 2.115 & 2.530 \\
$5 \mathrm{e}$ & 1.869 & 2.115 & 1.871 \\
$5 \mathrm{f}$ & 2.436 & 2.687 & 2.573 \\
$5 \mathrm{~g}$ & 2.520 & 2.673 & 2.504 \\
$5 \mathrm{~h}$ & 2.567 & 2.278 & 2.570 \\
$5 \mathrm{i}$ & 2.204 & 2.234 & 2.199 \\
$5 \mathrm{j}$ & 2.720 & 2.581 & 3.065 \\
$5 \mathrm{k}$ & 2.354 & 2.252 & 2.343 \\
$5 \mathrm{l}$ & 2.556 & 2.318 & 2.382 \\
$5 \mathrm{~m}$ & 2.334 & 2.397 & 2.329 \\
$5 \mathrm{n}$ & 1.744 & 1.819 & 1.742 \\
$5 \mathrm{o}$ & 2.553 & 2.584 & 2.550 \\
$5 \mathrm{p}$ & 1.730 & 1.562 & 1.609 \\
$5 \mathrm{q}$ & 2.179 & 2.208 & 2.173 \\
$5 \mathrm{r}$ & 1.830 & 1.833 & 1.834 \\
$5 \mathrm{~s}$ & 2.158 & 2.365 & 2.348 \\
$5 \mathrm{t}$ & 1.702 & 1.961 & 1.697 \\
$5 \mathrm{u}$ & 1.999 & 2.038 & 2.000 \\
$5 \mathrm{v}$ & 2.800 & 2.649 & 2.800 \\
\hline & $\mathbf{r}^{2}{ }_{\text {pred }}$ & $\mathbf{0 , 7 4 8}$ & $\mathbf{0 . 9 3 1}$ \\
& PRESS $^{2}$ & $\mathbf{0 . 5 7 5}$ & $\mathbf{0 . 2 3 3}$ \\
\hline & & &
\end{tabular}

lebih negatif dari atom $\mathrm{C}_{5}$ jika subtituen yang terikat pada atom $\mathrm{C}_{6}$ adalah atom klor $(\mathrm{Cl})$. Hal ini disebabkan oleh atom $\mathrm{Cl}$ sebagai gugus pendonor elektron (lemah) memberikan pengaruh melalui resonansi dan juga sebagai gugus penarik elektron (lemah) yang memberikan efek induksi lebih besar terhadap atom $\mathrm{C}_{1}$, hal ini dapat diketahui dari jarak atom $\mathrm{C}_{1}$ ke atom $\mathrm{Cl}$ sebesar $2.883 \AA$, lebih dekat dibandingkan jarak atom $\mathrm{C}_{5}$ ke atom Cl, yaitu sebesar $2.827 \AA$. Secara teori, pengaruh induksi atom halogen akan berkurang sesuai dengan jarak atom yang diinduksi. Sebaliknya, nilai atom $\mathrm{C}_{1}$ lebih positif dari atom $\mathrm{C}_{5}$ jika subtituen yang terikat pada atom $\mathrm{C}_{6}$ adalah molekul $\mathrm{CF}_{3}$. Jarak atom $\mathrm{C}_{1}$ ke molekul $\mathrm{CF}_{3}$ sebesar $2.690 \AA$, lebih dekat dibandingkan jarak atom $\mathrm{C}_{5}$ ke atom $\mathrm{CF}_{3}$, yaitu sebesar $2.654 \AA$, sehingga molekul $\mathrm{CF}_{3}$ yang dikenal sebagai gugus penarik elektron memberikan pengaruh melalui induksi yang lebih besar terhadap atom $\mathrm{C}_{1}$ dibandingkan terhadap atom $\mathrm{C}_{5}$. Dengan demikian, untuk meningkatkan aktivitas biologi senyawa turunan Quinolon-4(1H)-imines dapat dilakukan dengan mengganti subtituen yang terikat pada atom $\mathrm{C}_{6}$ dengan atom atau gugus lain yang memiliki sifat isosterik dengan molekul tersebut. Atom $\mathrm{N}_{14}$ memiliki nilai muatan yang relatif sama meskipun gugus penyumbang elektron yang terikat pada atom $\mathrm{N}_{14}$ berbedabeda. Perbedaan ini tidak memberikan pengaruh yang signifikan terhadap nilai muatan $\mathrm{N}_{14}$ karena perubahan struktur hanya pada panjang rantai karbon saja. Dalam molekul Quinolon-4(1H)imines, atom Nitrogen $(\mathrm{N})$ memiliki peran penting dalam peningkatan aktivitas antimalaria. 
Deskriptor yang paling berperan terhadap aktivitas antimalaria turunan Quinolon-4 $(1 \mathrm{H})$ imines adalah qC1, qC5, qC11, qN14 dan log P. Hubungan antara struktur Hubungan antara struktur dan aktivitas antimalaria turunan Quinolon-4(1H)-imines lebih tepat digambarkan sebagai hubungan non-linear yang ditunjukkan oleh nilai $r^{2}$ sebesar 0,931 menggunakan metode ANN. Dengan demikian, model hasil analisis dapat digunakan untuk mendesain senyawa antimalaria baru turunan Quinolon-4(1H)-imines.

\section{DAFTAR PUSTAKA}

Dondorp, A., Phyo, A. P., Tarning, J., Ph, D., Lwin, K. M., Ariey, F., ... White, N. J. (2009). Artemisinin Resistance in Plasmodium falciparum Malaria. The NEW ENGLAND JOURNAL of MEDICINE, 361;5(July 30, 2009), 455-467.

Frimayanti, N., Yam, M. L., Lee, H. B., \& Othman, R. (2011). Validation of Quantitative Structure-Activity Relationship (QSAR) Model for Photosensitizer Activity Prediction. International Journal of Molecular Sciences, 12, 8626-8644. https://doi.org/10.3390/ijms12128626

Golbraikh, A., Shen, M., Xiao, Z., Xiao, Y., \& Lee, K. (2003). Rational selection of training and test sets for the development of validated QSAR models. Journal of Computer-Aided Molecular Design, 17, 241-253.

Goodarzi, M., Freitas, M. P., \& Ghasemi, N. (2010). European Journal of Medicinal Chemistry Original article QSAR studies of bioactivities of 1- ( azacyclyl ) -3-arylsulfonyl$1 \mathrm{H}$-pyrrolo [ 2 , 3- b ] pyridines as 5-HT 6 receptor ligands using physicochemical descriptors and MLR and ANN-modeling. European Journal of Medicinal Chemistry, 45(9), 3911-3915.

https://doi.org/10.1016/j.ejmech.2010.05.045

Habibi-Yangjeh, A., Danandeh-Jenagharad, M., \& Nooshyar, M. (2006). Application of artificial neural networks for predicting the aqueous acidity of various phenols using QSAR, 338347. https://doi.org/10.1007/s00894-0050050-6

Kaur, K., Jain, M., Reddy, R. P., \& Jain, R. (2010). Quinolines and Structurally Related Heterocycles as Antimalarials. European Journal of Medicinal Chemistry, 45(8), 3245-3264. https://doi.org/10.1016/j.ejmech.2010.04.011

Larif, M., Adad, A., Hmammouchi, R., Taghki, A. I., Soulaymani, A., Elmidaoui, A., ... Lakhlifi, T. (2013). Biological activities of triazine derivatives. Combining DFT and QSAR results. Arabian Journal of Chemistry. https://doi.org/10.1016/j.arabjc.2012.12.033

Mishra, M., Mishra, V. K., Senger, P., Pathak, A. K., \& Kashaw, S. K. (2013). Exploring QSAR studies on 4-substituted quinazoline derivatives as antimalarial compounds for the development of predictive models. Medicinal Chemistry Research. https://doi.org/10.1007/s00044-013-0744-8

Motta, L. F., \& Almeida, W. P. (2011). Quantitative Structure-Activity Relationships ( QSAR ) of A Series of Ketone Derivatives as AntiCandida Albicans. International Journal of Drug Discovery, 3(2), 100-117.

Ressurreição, A. S., Gonçalves, D., Sitoe, A. R., Albuquerque, I. S., Gut, J., Góis, A., ... Moreira, R. (n.d.). Structural Optimization of Quinolon-4 ( $1 \mathrm{H}$ ) -imines as Dual-Stage Antimalarials $\square$ : Toward Increased Potency and Metabolic Stability, 4, 1-11.

Su, Q., \& Zhou, L. (2006). QSAR modeling of AT1 receptor antagonists using ANN, 869-875. https://doi.org/10.1007/s00894-006-0105-3

Ventura, C., Latino, D. A. R. S., \& Martins, F. (2013). European Journal of Medicinal Chemistry Comparison of Multiple Linear Regressions and Neural Networks based QSAR models for the design of new antitubercular compounds. European Journal of Medicinal Chemistry, 70, 831845. https://doi.org/10.1016/j.ejmech.2013.10.029

Verma, R. P., \& Hansch, C. (2009). Camptothecins: a SAR/QSAR study. Chemical Reviews, 109(1), 213-35. https://doi.org/10.1021/cr0780210

WHO. (2013). World Malaria Report 2013. 
